\title{
Role of Neuron-Glial Junctional Domain Proteins in the Maintenance and Termination of Neuronal Migration across the Embryonic Cerebral Wall
}

\author{
Eva S. Anton, ${ }^{1}$ Richard S. Cameron, ${ }^{2}$ and Pasko Rakic ${ }^{1}$ \\ 1Section of Neurobiology, Yale University School of Medicine, New Haven, Connecticut 06510-8001, and 2/nstitute of \\ Molecular Medicine and Genetics, Department of Medicine, Medical College of Georgia, Augusta, Georgia 30912-3175
}

\begin{abstract}
To identify glial membrane proteins that contribute to the process of neuronal migration in the developing brain, we developed a polyclonal antiserum (D4) and a monoclonal antibody (NJPA1: neuron-glial junctional polypeptide antibody) that recognize membrane proteins localized to the plasmalemmal junction between migrating neurons and adjacent radial glial fibers (Cameron and Rakic, 1994). Here, we show that in the developing cerebral cortex, immunoreactivity for these junctional polypeptides is present throughout the neuronal migratory pathway but becomes minimal or absent where radial glial cell processes enter the marginal zone region, the barrier at which newly arrived neurons normally stop their migration and detach from their glial fiber substrate. We thus tested, using imprints of embryonic cerebral wall and slice preparations, whether the junctional membrane proteins detected by our antibodies contribute to the regulation of neuronal migration in the cerebral
\end{abstract}

cortex. The rate of neuronal migration on glial cell substrates was reduced significantly in the presence of D4 or NJPA1 antibodies. Antibody exposure typically led to the withdrawal of leading processes, changes in microtubular organization and, in some instances, to detachment of neurons from their glial cell substrates. These results suggest that the polypeptides recognized by the D4 and NJPA1 antibodies are essential for the maintenance of normal neuronal migration. Dismantling of neuron-glial cell junctional domains formed by these membrane proteins may underlie neuronal cell detachment from glial migratory substrates at the interface between cortical plate and marginal zone in the developing cerebral wall.

Key words: neuronal migration; neuron-glial cell junctions; plasmalemmal microdomains; cell adhesion; developing cerebral cortex; stop signal for cell migration
Neuronal cell migration in the developing vertebrate CNS ensures that postmitotic neurons generated in the embryonic ventricular zone acquire their proper positions in the mature brain. The final position of a neuron is a crucial determinant of its morphology, synaptic connectivity, and function (Sidman and Rakic, 1973; Caviness and Rakic, 1978; Rakic, 1988, 1990). Moreover, defective migratory behavior of neurons is thought to be the underlying cause of several congenital cortical disorders (Evrard et al., 1978; Barth, 1987; Volpe, 1987; Rakic, 1988b, 1990; Caviness et al., 1989; Rorke, 1994; Reiner et al., 1995). Thus, an understanding of the dynamics and molecular mechanisms of neuronal cell migration would help in understanding normal cortical development as well as in deciphering the pathogenesis of various developmental disorders.

Translocation of a neuron from the proliferative ventricular zone of the embryonic cerebral vesicle to its specific final location in the cortical plate involves two processes: (1) active migration along an appropriate pathway, and (2) arrest of migration and exit from the migratory substrate at the appropriate laminae or nuclei. Observations in the past two decades indicate that elongated radial glial cell fibers serve as the primary migratory guides for

Received Oct. 30, 1995; revised Jan. 11, 1996; accepted Jan. 16, 1996.

This research was supported by Public Health Service grants from National Institutes of Health (NS14841, NS22807) to P.R., a Public Health Service Fellowship to E.A., and a Medical College of Georgia Research Institute grant to R.S.C. Wc thank E. Zelazny for providing technical assistance for this work.

Correspondence should be addressed to Eva S. Anton, Section of Neurobiology, Yale University School of Medicine, New Haven, CT 06510-8001.

Copyright $\odot 1996$ Society for Neuroscience $0270-6474 / 96 / 162283-11 \$ 05.00 / 0$ neurons in the mammalian brain (Rakic, 1971, 1972, 1990; Gray et al., 1990; Hatten and Mason, 1990; Misson et al., 1991; O'Rourke et al., 1995). The radial movement of neurons stops abruptly at the interface between cortical plate and cell sparse marginal zone. The "stop" signal for neuronal cell migration is thought to be provided either by the afferent fibers that migrating neurons encounter near their target location or by the ambient neuronal cell population that had already reached their final position (Sidman and Rakic, 1973; Hatten, 1990, 1993; Hatten and Mason, 1990; D'Arcangelo et al., 1995; Ogawa et al., 1995). Alternately, a change in the cell surface properties of the radial glial substrate may signal a neuron migrating on it to stop, detach, and differentiate.

Evidently, a dynamic regulation of multiple cellular events such as cell-cell recognition, adhesion, transmembrane signaling, and cell motility events underlies the process of neuronal migration (Lindner et al., 1983; Grumet et al., 1985, 1992; Antonicek et al., 1987; Chuong et al., 1987, 1990; Edmonson et al., 1988; Rutishauser and Jessell, 1988; Sanes, 1989; Hatten and Mason, 1990; Stitt and Hatten, 1990; Misson et al., 1991; Takeichi, 1991; Galileo et al., 1992; Komuro and Rakic, 1992, 1993, 1995; Shimamura and Takeichi, 1992; Fishman et al., 1993; Hatten, 1993; Rakic et al., 1994; Cameron and Rakic, 1994; Stipp et al., 1994; Rakic and Komuro, 1995). With a few exceptions (Antonicek et al., 1987; Feng and Heintz, 1994, 1995), the molecules that have been identified thus far as potential regulators of directed neuronal cell migration are neuronal cell surface elements primarily involved in neuron-neuron or neuron-glial cell interactions. The membrane components specific to the radial glial cells that are critical for 
neuronal cell migration remain mostly uncharacterized. To identify heterotypic recognition molecules that are present on the radial glial cell surface and can be used by migrating neuron as markers for finding their way to the cortex, we developed multiple rabbit polyclonal antisera and mouse monoclonal antibodies (mAbs) against CNS glial membrane proteins (Cameron and Rakic, 1994) (R. Cameron, N. Cho, J. Wren, P. Cameron, and P. Rakic, unpublished observations). Using these antibodies, we have previously identified and characterized two putatively novel membrane proteins ( $\sim 48$ and $72 \mathrm{kDa}$ ) that are localized to the points of contact between migrating neurons and radial glial cells.

The assembly of junctional complexes between the migrating neuronal cell soma and the radial glial cell process is thought to be critical in initiating and maintaining neuronal cell migration (Rakic, 1972, 1990; Garcia-Scgura and Rakic, 1985; Gregory et al., 1988; Fishell and Hatten, 1991). We thus hypothesize that the glial membrane proteins, found in the interstitial junction between migrating neurons and radial glial fibers and recognized by the D4 polyclonal and NJP1 mAbs, participate in critical stages of neuronal migration. In this study, using these antibodies and novel bioassays for cortical neuronal migration, we provide evidence for the functional significance of these polypeptides in the maintenance and, possibly, cessation of cortical neuronal migration.

\section{MATERIALS AND METHODS}

\section{Antibodies to glial cell surface microdomain proteins}

Polyclonal antiserum D4, which recognizes two radial glial cell surface antigens (48 and $72 \mathrm{kDa}$ ) localized to the junctional domain between migrating neurons and radial glial cells, has been described previously (Cameron and Rakic, 1994). A pancl of new mouse mAbs werc made against neonatal (postnatal day 6-8) cerebellar glial cells according to previously described methods and is reported separately (R. Cameron and P. Rakic, unpublished observations). Two mAbs from this panel, NJPA1 and NJPA2, were used in this study. Antibody NJPA1 is of the IgM isotype and recognizes an antigen of apparent molecular mass 72 $\mathrm{kDa}$, whereas antibody NJPA2 is of the $\mathrm{IgG}_{1}$ isotype and recognizes multiple uncharacterized neuronal and glial cell surface antigens. D4 antibodies were purified by ammonium sulfate precipitation followed by DEAE column chromatography. Fab fragments of $\mathrm{D} 4$ antibodies were made using ficin according to the manufacturer's instruction (Pierce, Rockford, IL). NJPA1 mAbs were purified using an immobilized goatanti mouse IgM column of a mouse IgM purification kit (Pierce), and NJPA2 mAbs were purified using Protein-G affinity chromatography (Mab trap kit, Pharmacia, Piscataway, NJ).

\section{Biochemical characterization of $m A b s$ to glial microdomains}

Membrane fractions were obtained from embryonic brains or C6 glioma ceils and polypeptides were separated either by one-dimensional or two-dimensional SDS-PAGE as described previously (Cameron and Rakic, 1994). Fractionated proteins were electrophoretically transferred to nitrocellulose (0.45 $\mu \mathrm{m}$, Bio-Rad, Hercules, CA) and processed for immunoblot analysis with D4, NJPA1, and NJPA2 antibodies. Immunoblots were incubated with antibodies overnight at $20^{\circ} \mathrm{C}$ before detection of bound antibodies with appropriate secondary antibodies [biotinylated goat anti-rabbit antibodies (1:2000 dilution) and avidin-peroxidase conjugate (1:1000 dilution) for D4 polyclonal antiserum (Vector Laboratories, Burlingame, CA); and for mouse mAbs, goat anti-rabbit-I'ss $(0.1$ $\mu \mathrm{Ci} / \mathrm{ml}$, DuPont NEN, Boston, MA) subsequent to incubation with a rabbit anti-mouse IgG or IgM bridge $(1: 1000)]$.

\section{Immunohistochemical procedures}

Cerebral cortices from rats (embryonic day 12 to adult; Sprague-Dawley) were removed, fixed in $4 \%$ paraformaldehyde, cut into $10-\mu \mathrm{m}$-thick sections in a cryostat, and collected onto gelatin-coated glass slides. After air-dried, sections were washed and blocked in Tris-buffered saline (TBS) containing $5 \%$ goat serum, $3 \%$ bovine serum albumin, and $0.01 \%$ Triton $\mathrm{X}-100$ for $15 \mathrm{~min}$, before incubating in primary antibodies for $1 \mathrm{hr}$ at room temperature. After three rinses in blocking solution, sections were incubated with appropriate $\mathrm{Cy} 3-$, rhodamine-, or fluorescein-conjugated secondary antibodies (1:200 dilution; Jackson Immunochemicals, West Grove, PA) for $1 \mathrm{hr}$ (Decamilli et al., 1983; Cameron and Rakic, 1994). Sections were then washed in TBS, counterstained with $10 \mu \mathrm{M}$ bisbenzimide, and mounted in mowiol (Calbiochem, I a Jolla, CA; $10 \%$ mowiol, $25 \%$ glycerol in $0.1 \mathrm{M}$ Tris with $p$-phenylenediamine) for observation in a Zeiss microscope equipped with catecholamine (excitation, $400-440 \mathrm{~nm}$; barrier, LP $470 \mathrm{~nm}$ ), rhodamine, and fluorescein filter sets. Cultures of embryonic rat cortical cells were processed identically, except the blocking buffer was devoid of Triton X-100.

To label living cerebrum, cerebral cortex from rat embryos (embryonic day 14-18) were removed and $100-\mu \mathrm{m}$-thick coronal sections were cut using a tissue chopper (McIlwain Instruments, Gomshall, Surrey, UK). Sections were then placed on $0.45 \mu \mathrm{m}$ biopore membrane inserts (Collaborative Research, Bedford, MA) and cultured in MEM/10\% horse serum containing primary antibodies for $2 \mathrm{hr}$ at $37^{\circ} \mathrm{C}$ or for $4 \mathrm{hr}$ at $4^{\circ} \mathrm{C}$ (to minimize internalization of antibodies through endocytosis). After three $5 \mathrm{~min}$ rinses in culture medium, sections were incubated with appropriate Cy3-conjugated secondary antibodies (1:200 dilution) at room temperature or at $4^{\circ} \mathrm{C}$ for 1 or $2 \mathrm{hr}$, respectively. Sections were then rinsed in culture medium three times as before. Membrane inserts with slices were cut and mounted in culture medium for immediate observation in a Zeiss microscope equipped with rhodamine and fluorescein filter sets. In some experiments sections were fixed in $4 \%$ paraformaldehyde before incubation with secondary antibodies.

\section{Bioassays for cortical neuronal migration}

Cortical imprint assay for neuronal migration. Cortical imprints containing a few cell layers of viable, developing cerebral wall or intact radial glia cells with migrating neurons attached to them were made using a modified tissue-imprinting technique used previously to study CNS glial cell physiology (Barres et al., 1990). Briefly, embryonic day 17-18 rat brains were removed and $200-\mu \mathrm{m}$-thick coronal sections of the cortices were prepared. Scetions were then incubated in CMF-PBS (calcium, magnesium-free-PBS) containing $10 \mathrm{U} / \mathrm{ml}$ papain for $10 \mathrm{~min}$. After the removal of papain, sections were incubated further for $10 \mathrm{~min}$ in MEM supplemented with $2 \mathrm{mg} / \mathrm{ml}$ ovomucoid inhibitor and $100 \mu \mathrm{g} / \mathrm{ml}$ DNase. After several washes in MEM supplemented with $10 \%$ horse serum, $5 \%$ fetal calf scrum, and $10 \mathrm{mg} / \mathrm{ml}$ glucose, sections were cultured on $1 \%$ nitrocellulose or $10 \mu \mathrm{g} / \mathrm{cm}^{2}$ Cell-Tak (Collaborative Research)-coated 35 $\mathrm{mm}$ petri dishes with glass bottoms (MatTek, Ashland, MA) in mininal volume of the above media for $10-24 \mathrm{hr}$. Cortical sections were then gently pressed against the culture substrate with a wet glass coverslip, and the culture dish was flooded with culture medium. This procedure lifts tissue sections off the substrate while leaving behind a few cell layer thick imprint of cerebral wall containing radial glial cells with migrating neurons attached to them.

Imprints were then maintained in the incubator for an additional 4-24 hr. Subsequently, imprints were transferred into the chamber of a microincubator $\left(37^{\circ} \mathrm{C}, 95 \% \mathrm{O}_{2} / 5 \% \mathrm{CO}_{2}\right.$; Narashighi Instruments, Greenvale, $\mathrm{NY}$ ) attached to the microscope stage. Cortical neurons migrating on radial glial cells were monitored using a Zeiss Axiovert 135 microscope (GHS filter block, 460-nm excitation wavelengths) equipped with a Zeiss W63 objective lens. Images were recorded every 5-15 min using a Panasonic TQ-3031 optic disk recorder and the Attoffuor Ratio Vision program (Atto Instruments, Rockville, MD). After 60-120 min of bascline recording, pure or Fab fragments of the experimental antibodies (1 $\mathrm{mg} / \mathrm{ml}$ ) were added to the cultures and monitoring continued for an additional 60-240 min. As controls, cultures were monitored unperturbed or after perfusing in media devoid of antibodies, or media containing control antibodies. Changes in the rate of cell migration, morphological features of migrating neurons and glial cell substrates, and the extent of neuronal-glial cell contact, were monitored before and after antibody perturbation. The extent of cell soma movement was divided by time elapsed between observations to obtain the rate of cell migration for each neuron studied. Statistical difference between experimental groups was tested by Student's $t$ test.

After recordings, the location of the cells were marked on the tissue culture substrate and cultures were fixed in $4 \%$ paraformaldehyde and processed for anti-glial fibrillary acidic protein (anti-GFAP, Dako, Carpinteria, CA), anti-neurofilament (Boehringher Mannheim, Indianapolis, IN), or anti-neuron-specific tubulin (TuJ-1 antibodies; generous gift from Dr. A. Frankfurter, University of Virginia) immunohistochemistry. GFAP immunohistochemistry was used to confirm that the cellular process on which the neurons migrated was glial cell in origin. Antineuron-specific tubulin labeling was used to confirm the identity of 
migrating cells as neurons. TuJ-1 immunohistochemistry was also used to evaluate any changes in the distribution and organization of microtubules before and after exposure to experimental antibodies.

Neuronal migration in cortical slice preparation. In this assay, newly generated neurons were labeled with 5-bromo- $2^{\prime}$-deoxyuridine (BrdU) and the extent of their migration away from the ventricular zone was measured after $24 \mathrm{hr}$ in culture. Briefly, pregnant rats (Charles River, Wilmington, MA) were injected intraperitoneally with $\mathrm{BrdU}(10 \mathrm{mg} / \mathrm{kg}$ body weight, dissolved in saline; Boehringher Mannheim) on embryonic day 18. After $45 \mathrm{~min}$, embryonic brains were removed and $200-\mu \mathrm{m}$-thick coronal slices were made and were cultured on $0.45 \mu \mathrm{m}$ biopore membranes (Millipore, Milford, MA) in MEM supplemented with $10 \%$ horse serum, $40 \mathrm{~mm}$ glucose, $1.8 \mathrm{~mm}$ glutamine, $24 \mathrm{mM} \mathrm{NaHCO}_{3}$, and $90 \mathrm{U} / \mathrm{ml}$ penicillin-streptomycin. In some experiments, culture medium was supplemented with $1 \mathrm{mg} / \mathrm{ml}$ purified antibodies. Slices were removed at various time points in culture and processed for $\mathrm{BrdU}$ immunohistochemistry as follows. Slices were fixed in $70 \%$ ethanol for $12 \mathrm{hr}$ at $4^{\circ} \mathrm{C}$. After three rinses in PBS, slices were fixed in $2 \mathrm{~N} \mathrm{HCl}$ for $1 \mathrm{hr}$ at room temperature, washed in PBS, and incubated for $4 \mathrm{hr}$ with an anti-BrdU $\mathrm{mAb}$ (1:75 dilution in PBS/0.5\% Tween-20; Becton Dickinson, San Jose, CA). Slices were then washed in PBS and incubated in 1:100 diluted anti-mouse IgG conjugated to Cy3 (Jackson Immunochemicals) for $2 \mathrm{hr}$. Five minutes before the end of incubation with the secondary antibodies, bis benzimide was added at a final concentration of $10 \mu \mathrm{M}$. After three rinses in PBS, biopore membrane inserts with the attached slices were cut out and mounted in mowiol/PPDA on a glass slide. Slices were observed in a Zeiss microscope equipped with catecholamine (excitation, 400-440 $\mathrm{nm}$; barrier, LP $470 \mathrm{~nm}$ ) and rhodamine filter sets. Images of BrdU and bis benzimide labeling in cortical slices were collected onto an optical disk using the ADOBE PHOTOSHOP program. The distribution and the extent of BrdU-labeled cell migration was analyzed using the Image $1.5(\mathrm{NIH})$ program.

To determine the maximum extent of migration of BrdU-labeled cells (i.e., migration index), the relative depth of the leading BrdU-positive cells within the cerebral wall was measured. The shortest distance between the BrdU-positive cells at the migratory front and the ventricular surface was measured, and this distance was divided by the width of the cortical slice in the same region to obtain the relative depth of the leading
BrdU cells within the slice. An average of these measurements from each slice indicates the maximum possible extent of neuronal cell migration (i.e., migration index) in that slice. Bis benzimide labeling of nuclei in the slices was used to demarcate the different regions (ventricular and subventricular zone, intermediate zone, and cortical plate) of the slice. After such demarcation the number of BrdU-positive cells/unit area were counted in the intermediate zone and cortical plate region of each slice. Due to the high density of the BrdU-positive cells in the ventricular and subventricular zones, individual BrdU-positive cells could not be quantitated reliably in these regions. Statistical difference between experimental groups was tested by Student's $t$ test.

Slices were obtained from cortical regions approximately corresponding to posterior frontal, parietal, and anterior occipital areas. To facilitate comparison between slices in an experiment, adjacent slices were cultured under different conditions in adjacent wells. After BrdU immunolabeling, identical regions of these sister slices cultured under different conditions were compared. Measurements were made mostly from the dorso-medial regions (i.e., overlying the medial region of the lateral ventricles) of the slices, because these regions in rodents appear to contain intact, radially aligned glial fibers (Misson et al., 1991).

\section{Image analysis}

Images from the above experiments were stored in an optical disk (Sierra, Pinnacle Micro Inc., Irvine, CA), and Adobe Photoshop program was used to assemble and label the panel of figures presented.

\section{RESULTS}

\section{Biochemical characterization of antibodies to neuronal-glial junctional domains}

Previously, using a polyclonal antiserum (D4) that was raised against neonatal CNS glial cells, we identified radial glial cell surface antigens of apparent molecular mass 48 and $72 \mathrm{kDa}$ (collectively referred as D4 antigens) as contributors to the formation of junctional domains found between migratory neurons and their radial glial cell substrates (Cameron and Rakic, 1994).
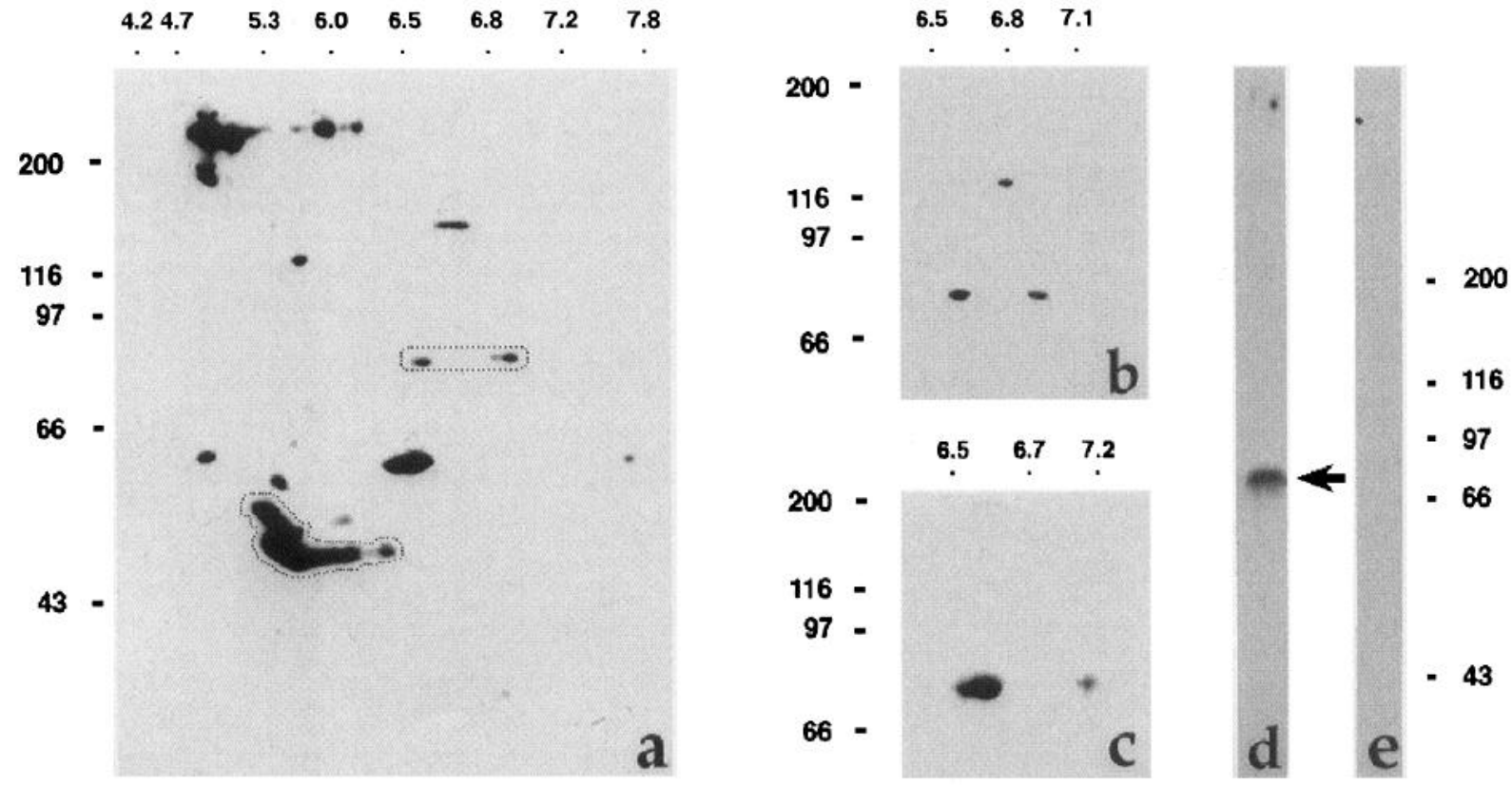

Figure 1. Identification of membrane polypeptides that contribute to the formation of $(a-c)$ glial cell surface microdomains. Membrane preparations from E18 cerebral cortex $(a)$ or C6 glioma cells $(b-e)$ were resolved by two-dimensional SDS-PAGE, electrophoretically transferred to nitrocellulose, and probed with D4 antiserum $(a)$, affinity-purified D4 polyclonal antibodies to $72 \mathrm{kDa}$ antigen $(b)$ (Cameron and Rakic, 1994) or NJPA1 mAb $(c)$. Previous studies demonstrated that the 48 and $72 \mathrm{kDa}$ antigens (outlined in $a$ ) are the cell surface components of the junctional domains recognized by the polyclonal antiserum D4 (Cameron and Rakic, 1994). NJPA1 mAb recognizes a $72 \mathrm{kDa}$ antigen component of the junctional domains, similar if not identical to that recognized by the D4 antibodies $(b, c)$. The $\sim 120 \mathrm{kDa}$ antigen in $b$ is the glycosylated version of the $72 \mathrm{kDa}$ antigen. In one-dimensional SDS-PAGE, NJPA1 recognizes a $72 \mathrm{kDa}$ band (arrow) identical to that recognized by the D4 polyclonal antiserum $(d)$. Control antibodies or secondary antibodies alone do not recognize this antigen $(e)$. Positions of molecular weight markers are indicated vertically, and $\mathrm{pH}$ values are indicated horizontally in each panel. 

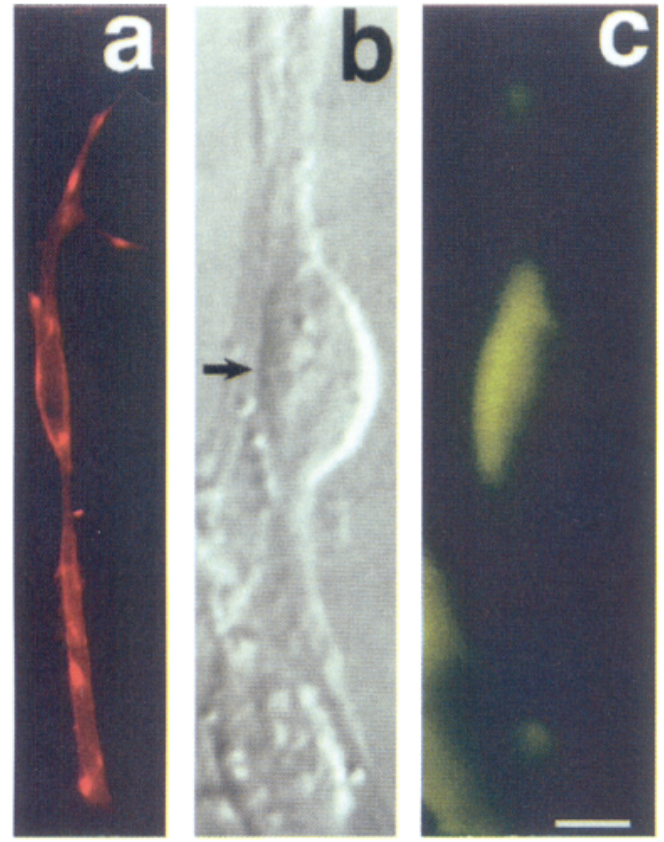

Figure 2. Distribution of NJP1 junctional domain antigen in radial glial cells and migrating cortical neurons. In radial glial cells, immunoreactivity is present at the plasmalemmal surface as small fluorescent microdomains $(a)$. In migrating neurons attached to radial glial processes $(b)$, immunoreactivity $(c)$ is found mainly at the site of contact between the neuronal cell soma and the glial process $(b$, arrow). Radial glial cell in $a$ is prepared from dissociated embryonic brain cultures, whereas cells in $b$ and $c$ are from a cortical imprint culture. Scale bar (shown in $c$ ): $a, 4 \mu \mathrm{m} ; b, 12.5 \mu \mathrm{m}$.
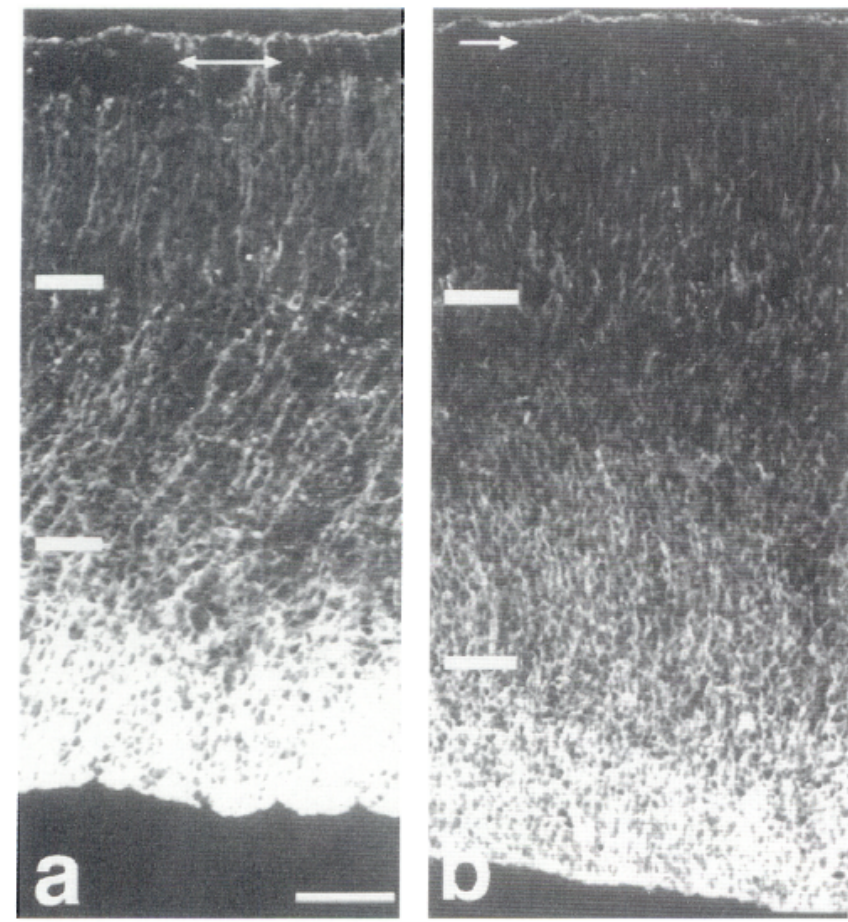

To obtain monospecific probes against these junctional domain antigens, a panel of mouse mAbs were generated using neonatal cerebellar glial cells as immunogens ( $\mathrm{R}$. Cameron, unpublished ovservations). mAbs that produced profiles of immunolabeling similar to that observed with the D4 polyclonal antiserum in primary radial glial cells and in neuronal-glial cell reconstitution cultures were selected for further analysis (R. Cameron, unpublished observations).

Here, we have characterized two of these mAbs, NJPA1 and NJPA2. In one-dimensional immunoblot analysis of membrane fractions prepared from astroglial cells, the mAb NJPA1 detected prominently a single polypeptide of apparent molecular mass 72 $\mathrm{kDa}$ (R. Cameron, unpublished observations) (Fig. 1d). In twodimensional (isoelectric focusing, SDS-PAGE) immunoblot analyses, NJPA1 mAb detected a single species of $72 \mathrm{kDa}$ with an isoelectric point of $\sim 6.6-7.0$ (Fig. $1 c, d$ ). This antigen overlaps in both apparent molecular mass and isoelectric point the $72 \mathrm{kDa}$ antigen identified by the polyclonal antiserum D4 (Fig. 1a-c). However, a direct comparison of the identities of the antigen recognized by the mAb NJPA1 and the $72 \mathrm{kDa}$ antigen recognized by the D4 polyclonal serum awaits sequence information on these polypeptides. By immunoblot analyses, the mAb NJPA2 detects multiple unidentified neuronal and glial cell surface polypeptides (data not shown).

\section{Immunohistochemical distribution of neuronal-glial junctional proteins during cortical development}

In mixed cultures of neurons and glia, the mAbs immunolabel microdomains on the free cell surface of cortical radial glial cells, but not on neurons (Fig. 2) (see also Cameron and Rakic, 1994). In cortical imprint preparations containing both migrating neuro-
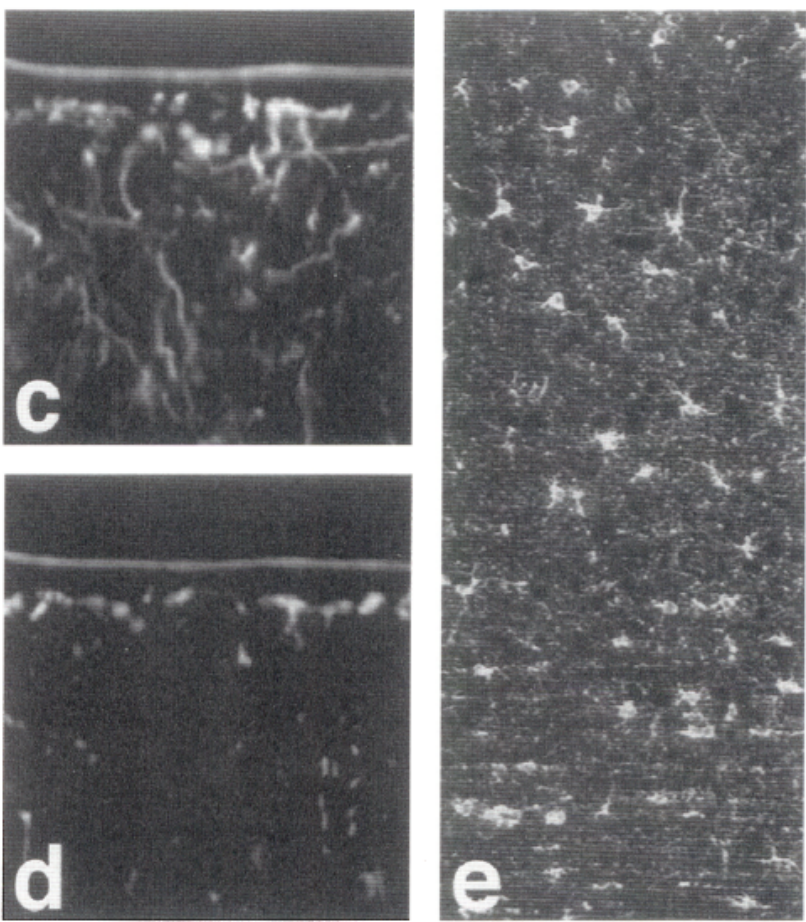

Figure 3. Indirect immunofluorescent analysis of NJP1 antigen during development of the cerebral cortex. Fluorescent micrographs are of NJPA1 mAb-labeled sagittal sections from embryonic day $16(a)$, embryonic day $19(b)$ telencephalic wall, and neonatal day 9 cortical plate region $(e)$. The marginal zone region of the neonatal day 1 cortical plate was double-labeled with anti-GFAP $(c)$ and NJPA1 mAb $(d)$. The glial processes spanning this region labels vigorously with anti-GFAP, but only occasionally with NJPA1 mAb. Arrows in $a$ and $b$ indicate the paucity of NJPA1 immunoreactivity in the marginal zone region. Horizontal bars in $a$ and $b$ demarcate the different regions of the cerebral wall: top, cortical plate; middle, intermediate zone; bottom, ventricular zone. Scale bar (shown in $a$ ): $a, b, 100 \mu \mathrm{m} ; c, d, 15 \mu \mathrm{m} ; e, 70 \mu \mathrm{m}$. 
nal cells and radial glial cells, immunolabeling is localized mainly to the sites where the neuronal cell soma and leading process were in contact with the surface of an elongated glial cell (Fig. 2b,c). In living embryonic brain slices, the NJPA $1 \mathrm{mAb}$ labels punctate cell surface domains on radial glial cells that appear to correspond to the sites of contact with migrating neurons (data not shown). Similar labeling pattern was also observed in living slices with D4 heterologous antisera containing antibodies to both 48 and 72 $\mathrm{kDa}$ junctional domain antigens.

In the developing rat cortex, NJPA1 immunoreactivity is not detectable on radial glial cells until after the initiation of neuronal cell migration around embryonic day 14. By embryonic day 16, when great numbers of neurons are in the process of migration, NJPA1 immunoreactivity is distributed throughout all developing cortical layers, but immunostaining is particularly prominent at the level of the ventricular, subventricular, and intermediate zones. Radial glial cells and, possibly neurons, are immunolabeled and radial glia can be observed coursing from the ventricular to pial surface. In labeled radial glial processes, NJPA1 immunoreactivity is typically distributed in a punctate manner, possibly representing the glial microdomains that are in linkage with migrating neurons. A general paucity in the NJPA1 immunoreactivity is observed in the segment of glia that traverses the marginal zone (arrow in Fig. $3 a$ ). At embryonic day 19, NJPA1 immunoreactivity shows a distribution similar to that observed at embryonic day 16 , including the striking absence of immunoreactivity in radial glial processes in the marginal zone (arrow in Fig. 3b). Prominent labeling of radial glial cells persists on neonatal day 1 . As in previous embryonic ages, the marginal zone region was mostly devoid of immunoreactivity (Fig. $3 c, d$ ). At postnatal day 9 and in the adult cortex, the pattern of NJPA1 immunostaining reflects the cellular distribution of astroglial cells (Fig. 3e). Neuronal cells at these ages are immunonegative. In contrast to NJPA1 mAb, NJPA2 mAb labeled embryonic brain tissue in a ubiquitous manner.

Taken together, our analysis of the distribution of NJP1 antigen during the development of cerebral cortex reveal a pronounced spatial and temporal correlation between the presence of this antigen on radial glial cell processes and neuronal migration: NJP1 immunoreactivity is not detectable on radial glial cells until neuronal cell migration has begun and immunoreactivity virtually disappears in the marginal zone region, which forms a barrier signaling the end of neuronal migration. We therefore examined the role of these antigens in the migration of cortical neurons, using two novel bioassays for cortical neuronal migration.

\section{Functional testing of antibodies to neuronal-glial junctional proteins in cortical "imprint" assay}

To test whether the junctional membrane proteins contribute to the regulation of neuronal migration in the cerebral cortex, we developed a new bioassay for cortical neuronal cell migration that is amenable to manipulation by extrinsic factors. Coronal sections embryonic day 17-18 rat cerebrum were cultured on Cell-Takcoated coverslips. After $24 \mathrm{hr}$, the attached slices were lifted off, leaving behind imprints of cerebral wall containing elongated glial cells with migrating neurons attached to them. Depending on the extent of adhesion, this imprinting procedure results in 1- to 3-cell-layer-thick cortical strips with viable cells and discernible cytoarchitecture. Often radial glial fibers with migrating neurons on them were seen in these imprints (Fig. 4). The rate of neuronal cell migration in such imprints averaged $10.1 \pm 0.3 \mu \mathrm{m} / \mathrm{hr}(n=$ 354) - a rate comparable to that observed in in vivo assays

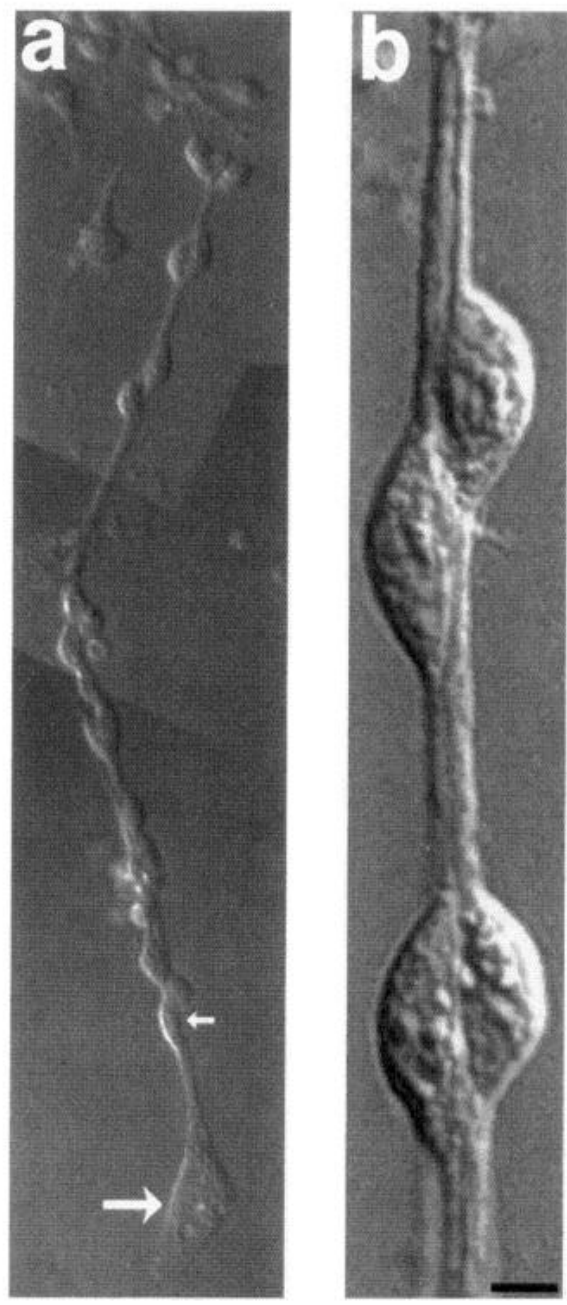

Figure 4. Cortical imprint assay for neuronal cell migration. Imprints of embryonic day 17-18 rat cortex were made on Cell-Tak-coated glass coverslips. In $a$, a typical imprint culture containing migrating neurons (small arrow) on a radial glial cell (large arrow) is seen. $b$, Migrating neurons from an imprint culture at a higher magnification. Migrating cortical neurons in this assay display characteristic leading and trailing processes. Scale bar (shown in $b$ ): $a, 15 \mu \mathrm{m} ; b, 4 \mu \mathrm{m}$.

(O'Rourke et al., 1991, 1992). Imprints of dorsal and medial regions of cortical slices (but not the lateral hemispheric regions) often yielded intact radial glial cells with migrating neurons attached to them, because those regions of cortical slices appeared to contain intact, rather than severed, radial glial fibers.

Changes in the migratory behavior of neurons in imprint cultures were monitored before and after the addition of polyclonal antiserum D4, NJPA1 mAbs, or NJPA2 mAbs. Antibodies were added either as Fab fragments or as purified whole molecules. The rate of neuronal cell migration on glial cell substrates was reduced significantly in the presence of the polyclonal antiserum D4 $(-43 \%)$ and the mAb NJPA1 $(-53 \%)$ but not the mAb NJPA2 (Figs. 5, 6). Within 45 min of antibody exposure neurons reduce the extent of their migration and begin to change from an elongated morphology characteristic of migrating neurons to a more rounded morphology characteristic of stationary neurons. Antibody exposure often led to withdrawal of leading processes, and in some instances ( $32 \%$ of cases) to detachment of neurons from their glial cell substrates (Figs. 5a,b, 7).

Withdrawal of processes of the migrating neurons was strikingly evident when migrating neurons were labeled with an antibody to 

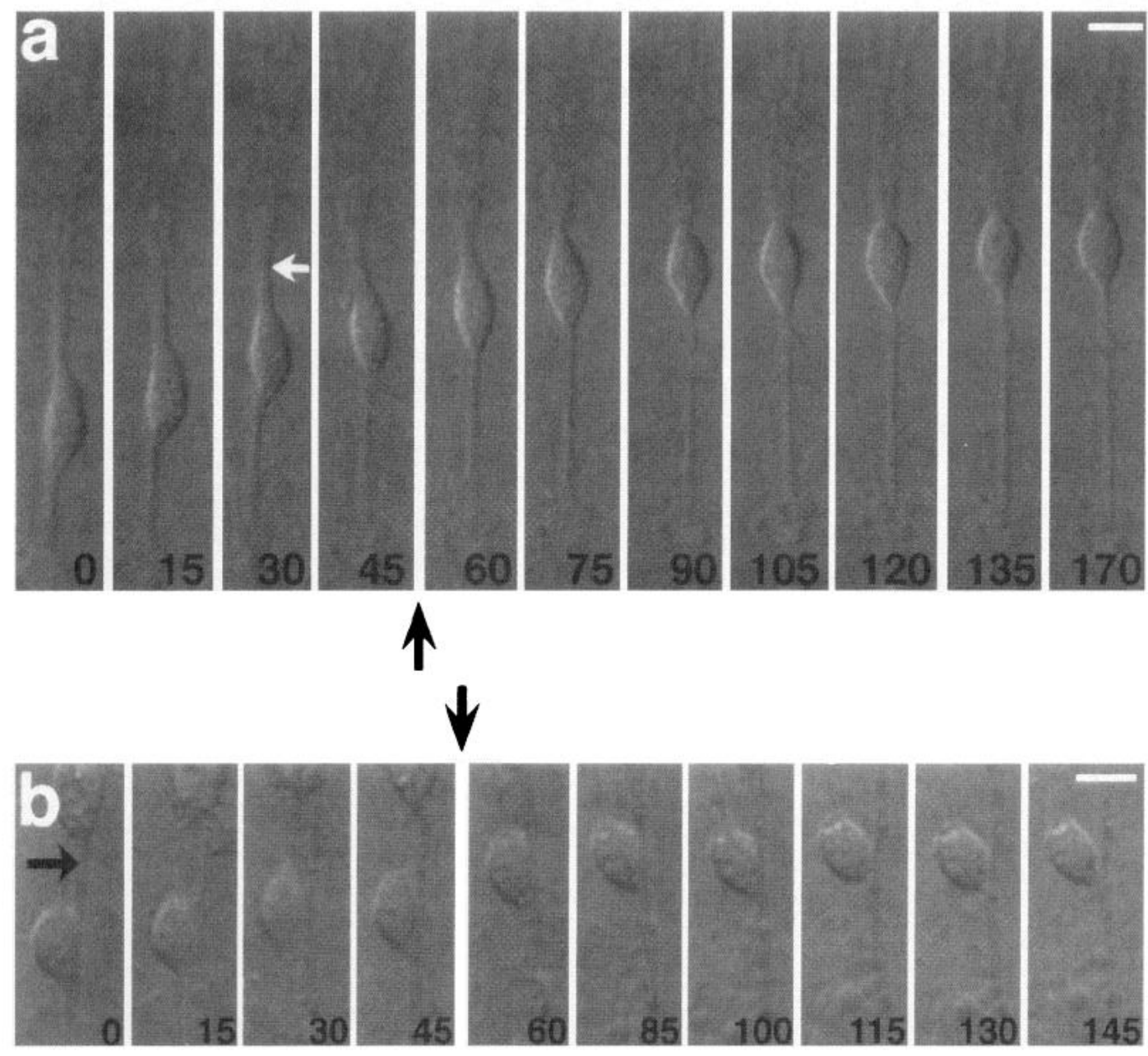

Figure 5. Exposure to D4 polyclonal antiserum and NJPA1 mAbs to junctional domain antigens leads to reduction or cessation of cortical neuronal migration in imprint cultures. Cortical imprint cultures were prepared as described in Materials and Methods. In $a$, a neuron migrating on a thick glial cell process was monitored before (panels to the left of black arrow) and after (panels to the right of black arrow) addition of purified NJPA1 mAbs. Minutes elapsed since the beginning of the recording are indicated at the bottom of each panel. Neuron was motile and exhibited a prominent leading process (arrow) before the addition of antibodies. After exposure to antibodies, this neuron reduced its rate of migration, became more rounded, withdrew its leading process, and eventually appeared to have stopped moving altogether. $b$, The changes in cell shape and eventual detachment from the glial process that frequently accompany exposure to junctional domain antibodies. Before exposure to D4 Fab fragments, this neuron exhibited the typical morphology of a migrating cell, with a leading and trailing process. However, after exposure to antibodies, this neuron appears to have retracted its processes, rounded up, and then detached from its glial substrate (arrow). Scale bars: $a, 9 \mu \mathrm{m} ; b, 10 \mu \mathrm{m}$.

neuron-specific $\beta_{\mathrm{III}}$-tubulin (TuJ-1; Lee et al., 1991) before and after exposure to D4 antiserum (Fig. 7). In migrating neurons, TuJ-1 labeled a thin cortex of microtubular network around the cell soma and dense, longitudinal arrays of microtubules in both the leading and trailing processes. A concentrated distribution of microtubules was also noticed in the region where the leading process exits cell soma. However, after exposure to the D4 antiserum, TuJ-1 immunoreactivity was restricted mainly to a denser network of microtubules circumscribing the cell soma (Fig. 7). These data suggest that a rearrangement of cytoskeletal machinery may underly the alterations in neuronal cell shape and cell motility observed subsequent to the disturbance of the specific junctions between migrating neurons and radial glial cells by the polyclonal antiserum D4. Exposure to a control mAb, NJPA2, or to rabbit nonimmune immunoglobulins had no significant effect on rate of neuronal cell migration. Radial glial cells did not exhibit any vigorous morphological changes after antibody exposure.

The effects observed with D4 polyclonal serum, which recognizes both the 72 and the $48 \mathrm{kDa}$ junctional antigens, suggest but do not definitively prove that the $48 \mathrm{kDa}$ junctional domain antigen is also an important component of normal cortical neuronal migration. Conclusive evaluation of the functional significance of the $48 \mathrm{kDa}$ antigen awaits the affinity purification of the antisera to the $48 \mathrm{kDa}$ antigen and the characterization of mAbs to it.

\section{Functional testing of antibodies to neuronal-glial junctional proteins in cortical slice assay}

To rule out the possibility that our imprint assay may be lacking in some complex neuron-neuron or neuron-substrate interactions important for cell migration in vivo, we also tested our antibodies in embryonic cortical slice cultures, which recapitulates the situation in vivo even more closely than the imprints. In this bioassay, newly generated cortical neurons were labeled with $\mathrm{BrdU}$ and the extent of their migration from the ventricular zone into the intermediate zone and cortical plate was measured after $24 \mathrm{hr}$ in culture. Neurons that are generated at a particular time point on embryonic day 18 were pulse-labeled with $\mathrm{BrdU}$ as described 


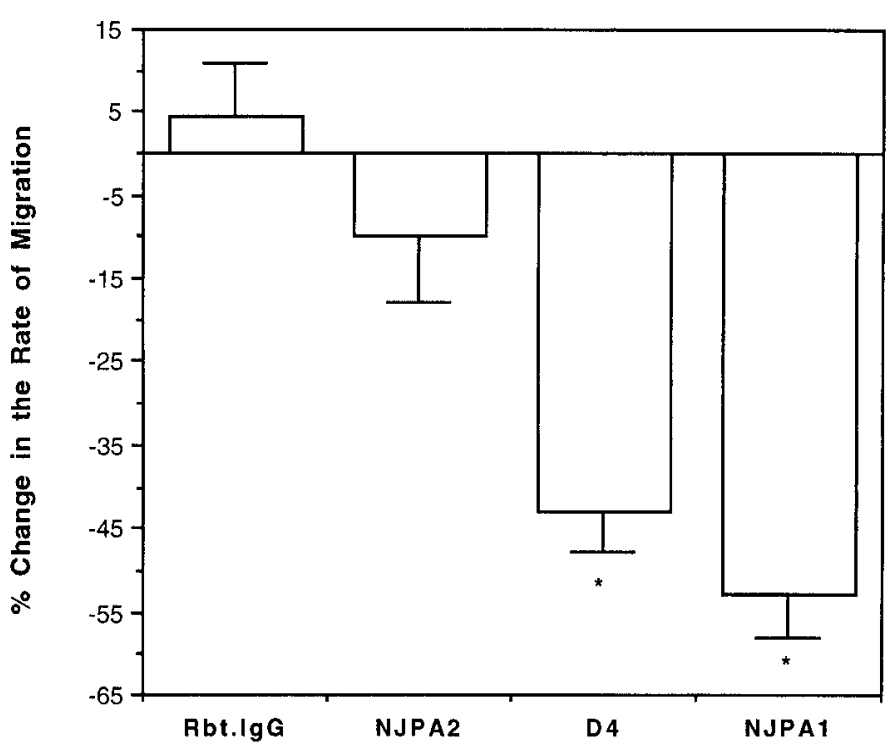

Figure 6. Effect of NJPA1, NJPA2 mAbs, and D4 polyclonal antiserum on cortical neuronal migration in imprint cultures. The rate of neuronal migration was measured before and after exposure to these antibodics. Purified $\mathrm{mAbs}$ were added at $1 \mathrm{mg} / \mathrm{ml}$. Fab fragments of D4 polyclonal antiserum and rabbit nonimmune IgGs were added at $100 \mu \mathrm{g} / \mathrm{ml}$. Exposure to NJPA1 and D4 antibodies significantly reduced the rate of migration by 53 and $43 \%$, respectively. NJPA $2 \mathrm{mAb}$, which recognizes multiple cell surfacc antigens, produced only a modest $9.8 \%$ decrease in the rate of migration. Fab fragments of rabbit IgG did not alter the rate of migration significantly. Number of cells analyzed in each group are as follows: NJPA1, 39; NJPA2, 53; D4, 87, rabbit IgG (Rbt. IgG), 38. Data shown are the mean \pm SEM for each group. Asterisks indicate that the NJPAl and $\mathrm{D} 4$ effects are significant when compared with the respective controls at $p$ $<0.05$. NJPA2 effect, when compared with the rabbit $\operatorname{lgG}$ effect, is not significant $(p>0.05)$.

previously (Takahashi et al., 1992; O’Rourke and McConnell, 1993). Labeled embryonic brains were removed, coronally sectioned into 200 - $\mu$ m-thick slices, and cultured on biopore membrane inserts with or without antibodies. At various time points, slices were removed and the location of BrdU-labeled cells was assayed by labeling the slices with an anti-BrdU antibody. At time 0 , labeled cells were found almost exclusively in the ventricular zone. Occasionally, a few BrdU-positive cells were detected in the intermediate zone or in the cortical plate (Fig. 8, panel 1a). After $24 \mathrm{hr}$, labeled cells were observed to be scattered throughout the intermediate zone and occasionally in the cortical plate. This change in cell position is considered to reflect active neuronal cell migration rather than passive cell displacement. When the migration of BrdU-labeled neurons was monitored in the presence or absence of junctional domain antibodies, we found that both the polyclonal antiserum D4 and the mAb NJPAl retarded the maximum extent of neuronal migration by $36 \%$ and $28 \%$, respectively (see Fig. 8, panel $1 b, c$, panel 2). This reduction in the rate of migration was reflected in the reduced number of cells that migrated away from the ventricular zone into the intermediate zone and cortical plate in the presence of function blocking antibodies. In the absence of migration blocking antibodies, almost 2.3 (D4)- to 3 (NJPA1)-fold more BrdU-positive cells migrated into the intermediate zone and nearly 6 (D4)- to 10 (NJPA1)-fold more BrdU-positive cells migrated to the cortical plate (see Fig. 8, panel 3). Neither the rabbit immunoglobulins nor the control antibody, NJPA2, produced any significant effects.

\section{DISCUSSION}

Migrating neurons in the developing CNS form specialized membrane contacts variably referred to as junctional domains or interstitial junctions with the underlying radial glial cell substrate (Gregory et al., 1988; Cameron and Rakic, 1994). Such specialized membrane contacts are hypothesized to be critical elements in the maintenance of directed neuronal cell migration along radial glial cell fibers (Rakic et al., 1994). In this study, we demonstrate that putatively novel polypeptide components (48 and $72 \mathrm{kDa}$ ) of the junctional domains play a role in the maintenance of normal cortical neuronal migration and that dismantling of these specialized contacts in the marginal zone region may signal neurons to cease their migration and detach from their glial substrates.

The functional properties of the junctional domain antigens were analyzed in two different cortical neuronal migration assays, cortical imprints and slice preparations, which have varying degrees of histotypic complexity. In the first assay, imprints of embryonic cerebral wall containing intact radial glial cells with migrating neurons attached to them were used. In the second assay, newly generated neurons were labeled with $\mathrm{BrdU}$ and the extent of their migration into the cerebral wall away from the ventricular zone was monitored. In both assays, molecular cues necessary for cortical neuronal cell migration and pattern formation are maintained with minimal perturbance. Thus, in combination, these two assays provide useful tools to analyze the nature of glia-neuron interactions and its implications during the process of neuronal migration in the developing cerebral cortex. In the first assay, cortical neurons migrate solely on radial glial cell substrates in a radial direction, whereas in the second assay BrdU-labeled neurons migrate both radially and tangentially, with radial migration along radial glia being the predominant mode of choice (O'Rourke et al., 1992, 1995; Rakic, 1995). In both assays, perturbing the junctional contacts formed between migrating neurons and radial glia lead to reduction and, at times, cessation of neuronal cell migration. Because junctional domains as evinced by our antibodies do not form between neurons, the effect of our antibodies is primarily on the radial "gliophilic" neuronal migration (Rakic, 1985). Previous electron microscopic studies and recent confocal microscopic studies also suggest that some of the nonradially migrating cortical neurons may utilize glia as migratory substratum (Boulder Committee Report, 1970; Rakic, 1971, 1972; O'Rourke et al., 1992, 1995). Whether these neurons form transient junctional domains with the radial glial fibers as they translocate across the cerebral wall in the tangential direction remains unclear. Neurons, having been blocked in their migration on radial glia in our slice assay, may also have dispersed more tangentially on other neurons or axonal fibers. Regardless, our studies support the idea that the molecular basis of the radial gliophilic neuronal cell migration is unlike that of the "neurophilic," and presumably mainly tangential, neuronal cell migration in the developing telencephalon (Rakic, 1990, 1995; Tomasiewicz et al., 1994).

$\Lambda$ migrating neuron attaches itself to the radial glial substrate primarily by its leading process and cell soma. Only the actively migrating neurons form the specialized junctional domains or the interstitial densities with the apposing glial fibers (Gregory et al., 1988; Cameron and Rakic, 1994), whereas the stationary neurons form desmosomes or puncta adhaerentia. The specialized regional accumulations of membrane proteins at the apposition of migrating neurons and radial glial cells may function in migration by orchestrating cell-cell recognition, adhesion, transmembrane 


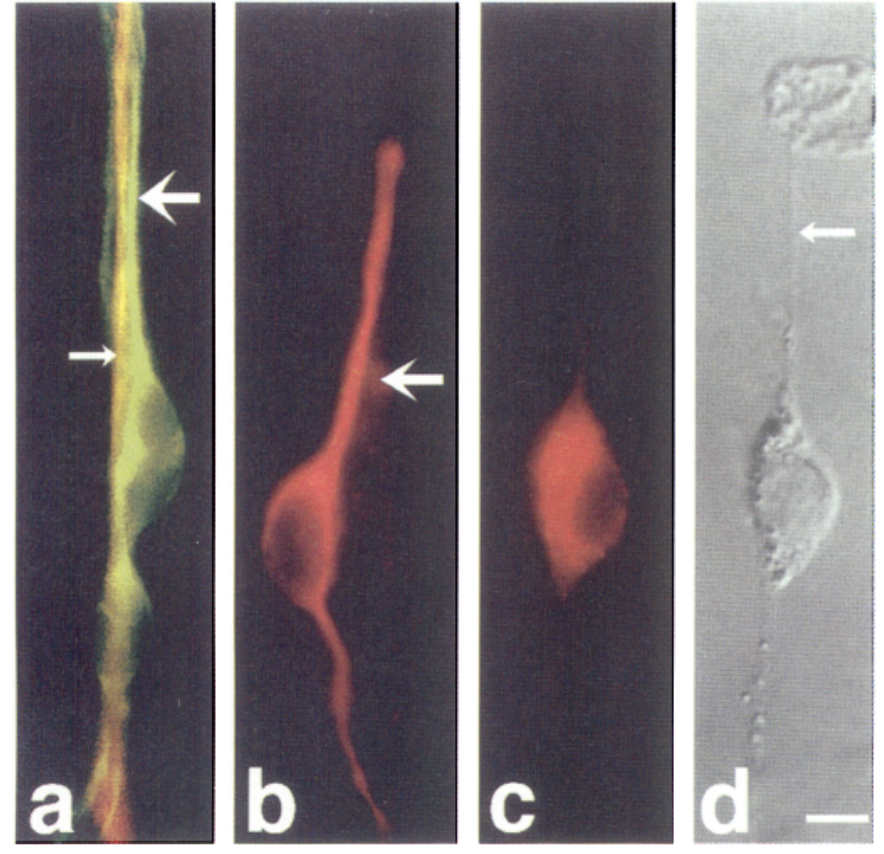

Figure 7. Distribution of neuron-specific class III $\beta$-tubulin in migrating cortical neurons before $(a, b)$ and after $(c)$ exposure to D4 polyclonal antiserum. TuJ-1 mAb to neuron-specific class III $\beta$-tubulin labels both the leading and trailing processes in a migrating neuron $(a, b)$. In the soma of these cells, TuJ-1 labels a thin cortex of microtubular network. $c$ illustrates a cortical neuron after exposure to D4 antiserum. The leading and trailing processes are mostly withdrawn, and microtubules appear to be redistributed in a denser network around cell soma. In $a$, the glial process (small arrow) used by the migrating neurons is labeled with anti-GFAP, whereas in $b$ and $c$, the glial processes are unlabeled and are barely visible (arrow, $b$ ). $d$ is a phase-light image of $c$, illustrating that the neuron shown in $c$ is attached to a glial process (small arrow, $d$ ) and has withdrawn its processes. TuJ-1 label was visualized with anti-mouse conjugated to $\mathrm{Cy} 3(b, c)$ or FITC $(a)$. GFAP label in $a$ was visualized with anti-rabbit conjugated to Cy3. Scale bar, $5 \mu \mathrm{m}$.

signaling, and or motility. Our antibodies (D4, NJPA1), recognizing the functionally active 48 and $72 \mathrm{kDa}$ cell surface components of the junctional domains, presumably disrupt the functional integrity of these special attachment sites between migrating neurons and radial glial cells, thus retarding and eventually ending normal neuronal migration.

The integrity of junctional complexes appears to depend on their association with microtubule cytoskeleton (Gregory et al., 1988; Cameron and Rakic, 1994). Junctional domain associated microtubules are thought to play a role in force generation during cell movement, in addition to being vital for the elaboration and maintenance of junctional domains (Gregory et al., 1988). Furthermore, specific cell-cell interactions between migrating neurons and radial glial cells mediated by the junctional domain antigens may modulate the properties of each others cytoskeleton, akin to that observed between developing peripheral axons and Schwann cells (Kirkpatrick and Brady, 1994). When labeled with TuJ-1, an antibody specific to neuronal class III $\beta$ - tubulin, migrating neurons displayed longitudinal arrays of microtubules in both leading and trailing processes, and a thin cortex of microtubule network in the cell soma. After exposure to junctional domain antibodies, most neurons display shorter processes and a thicker cortex of microtubule network in their cell soma. Interestingly, it appears that disruption of microtubules, but not actin
8.1
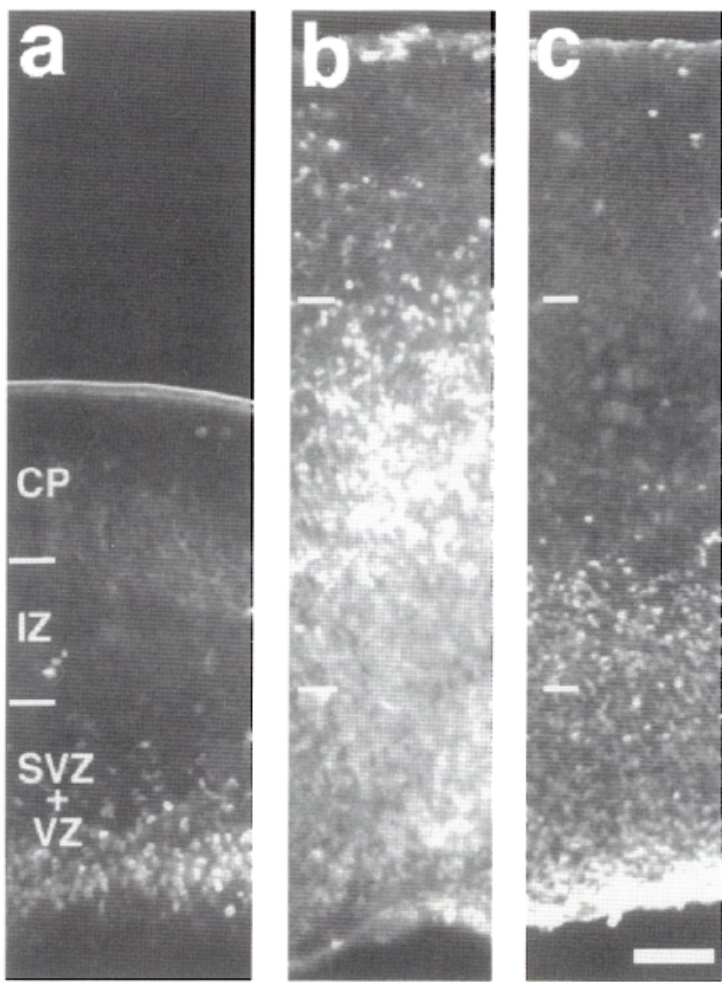

Figure 8. Effect of NJPA1, NJPA2 mAbs, and D4 polyclonal antiserum on migration of newly generated BrdU-positive neurons in slice cultures. Panel 1 illustrates BrdU-positive cell distribution in embryonic day 18 cortical slices after $0 \mathrm{hr}$ in culture $(a)$, after $24 \mathrm{hr}$ in culture in medium supplemented with rabbit immunoglobulins $(b)$, and after $24 \mathrm{hr}$ in culture with D4 polyclonal serum $(c)$. At $0 \mathrm{hr}, \mathrm{BrdU}$-labeled cells are restricted to a sharp band in the ventricular zone $(V Z)$. In the next $24 \mathrm{hr}$, newly generated BrdU-positive neurons migrated out into the intermediate zone $(I Z)$ and cortical plate $(C P)$ under control conditions $(b)$. However, in the presence of D4 antibodies $(c)$ their migration is impeded and, thus, they did not migrate as far as their counterparts in slices cultured in the presence of rabbit immunoglobulins $(b)$. (SVZ), Subventricular zone. Scale bar, $37.5 \mu \mathrm{m}$.

filaments, may also adversely affect neuronal-glial adhesion (Rivas and Hatten, 1995). Perhaps, disrupting junctional complexes with the antibodies may have led to alterations in functional properties of microtubule cytoskeleton, causing changes in cell shape, motility, and integrity of junctional adhesion complexes (Rivas and Hatten, 1991; Falconer et al., 1992; Rakic et al., 1994, 1996; Moskowitz and Oblinger, 1995).

We are unable to determine, using light microscopy, whether junctional antigens are localized to the glial compartment alone or to both neuron and glial membranes of the junction. Glial junctional domain antigens may interact with an identical ligand on the neuronal cell surface in a homophilic manner, or they may interact with a different ligand(s) on the neuronal cell surface in a heterophilic manner. Alternatively, as in the case with L1, glial junctional antigens in addition to interacting homophilically with similar antigens on neuronal surface, may also be capable of binding heterophilically to other neuronal cell surface molecules such as astrotactin (Fishell and Hatten, 1991). However, further antigen binding studies and electron microscopic immunohistochemistry of the attachment sites of migrating neurons and radial glia will be needed to clarify the homophilic or heterophilic nature of the junctional domain antigen interactions.

Arrest of neuronal cell migration and exit from the radial glial 

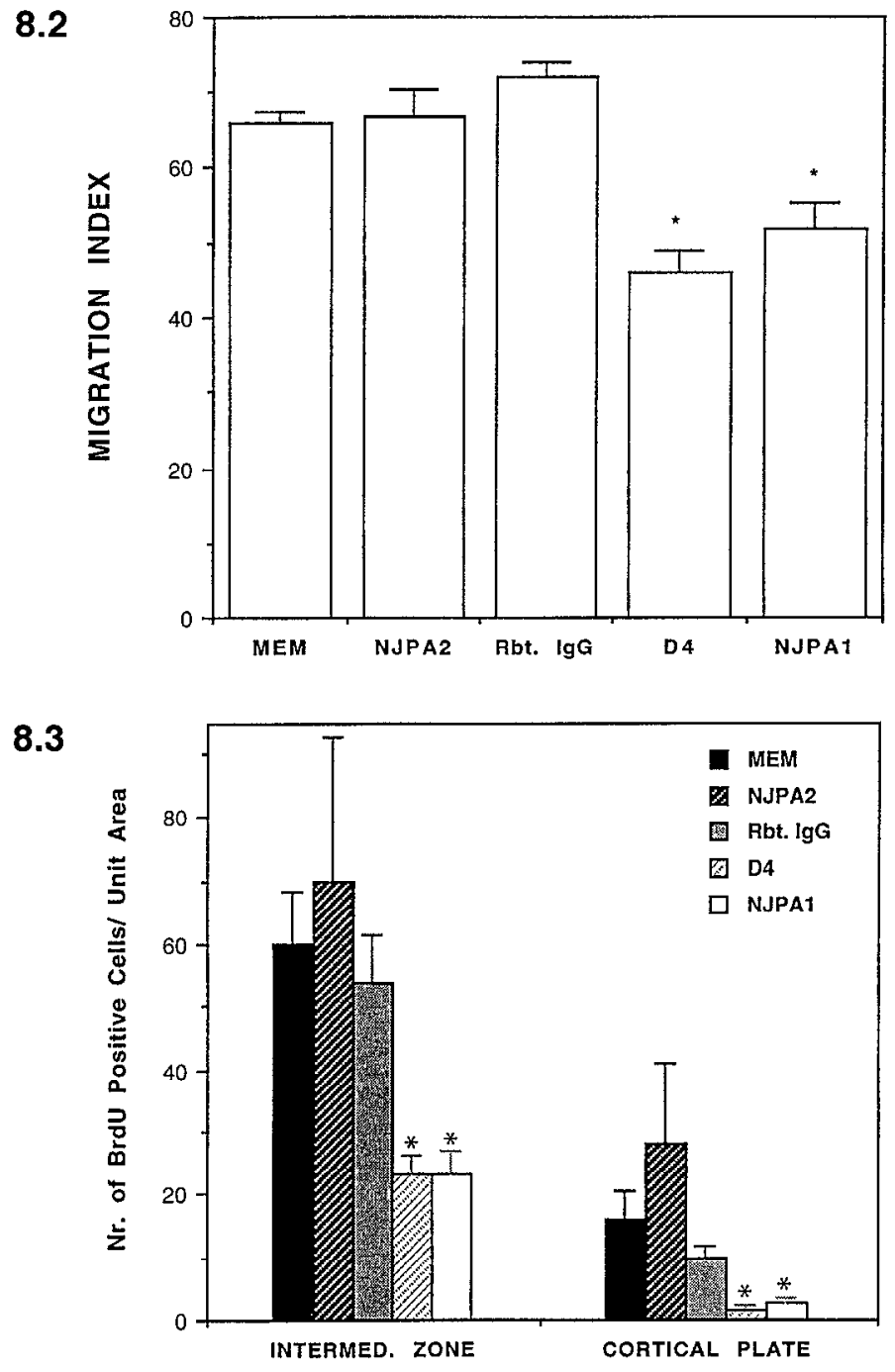

Figure 8. (continued). Panel 2 is a histogram showing the relative depth (migration index) of the leading BrdU-positive cells within cerebral wall, under different experimental conditions. Migration index was measured as follows: the shortest distance between the BrdU-positive cells at the migratory front and the ventricular surface was measured, and this distance was divided by the width of the cortical slice in the same region to obtain the relative depth of the leading BrdU cells within the slice. An average of these measurements from each slice indicates the maximum possible extent of neuronal cell migration in that slice. Both D4 and NJPA1 antibodies significantly retarded the maximum extent of migration by 36 and $28 \%$, respectively. The unsupplemented culture medium (MEM/10\% HS), NJPA2 antibodies, and rabbit immunoglobulins did not affect neuronal cell migration in these slices. This is reflected in the number of BrdU-positive cells that were found in the intermediate zone (INTERMED. ZONE) and CORTICAL PLATE regions under these different experimental conditions (panel 3). Almost 2.3- to 3-fold more BrdU-positive cells managed to reach the intermediate zone under control conditions compared with the ones exposed to D4 or NJPAl antibodies. Similarly, nearly 6 - to 10 -fold more BrdU-positive cells were found in cortical plate in the absence of migration-blocking antibodies. In the presence of functional antibodies to junctional domains, the extent of neuronal cell migration was retarded, in terms of both numbers and distance of migration. Panel 3, Unit area $=10,000 \mu \mathrm{m}^{2}$. Number of slices analyzed in each group are as follows: MEM, 22; rabbit IgG, 10; NJPA1, 7; NJPA2, 8; D4, 13. Data shown are the mean \pm SEM for each group. Asterisks indicate that the NJPA1 and D4 effects are significant compared with the respective controls at $p<0.05$. migratory substrate at appropriate cortical laminae is as important as the process of migration itself. The "stop" signal for the radial neuronal migration is thought to be provided either by the afferent fibers that migrating neurons encounter near their target location or by the ambient neurons that had already reached their final position (Sidman and Rakic, 1973; Hatten, 1990, 1993; Hatten and Mason, 1990). Our studies support a third possibility: the cell surface properties of glial substrate change when a neuron reaches its appropriate location, thus signaling a neuron to end its migration. Immunoreactivity of junctional domains localized between migrating neurons and radial glial fibers disappears or diminishes at the interface between the marginal zone and cortical plate (prospective layers I and II), where the movement of all neurons, irrespective of their phenotype, abruptly stops. The expression of the junctional microdomain protcins decreases sharply at the segment of the radial glial fiber where neurons detach from it. This pattern of in situ immunolocalization of junctional domain antigens, in combination with the functional studies, suggests that dismantling of the specialized neuron-glial junctional complexes formed by the membrane proteins recognized by our antibodies may underlie cessation of neuronal cell migration and eventual neuronal detachment from the glial substrates at appropriate locations in the developing cortical plate. It may be significant for the proposed hypothesis, that individual radial glial fiber usually split into several branches precisely at the border of the layer I and II (Rakic, 1972). Thus, indicating that at this point either local conditions or internal cell organization abruptly changes (Schmechel and Rakic, 1978; Cameron and Rakic, 1991; Rakic, 1995). Such abrupt changes in the cell surface properties of radial glial path coupled with the induction of specific cell--cell recognition interactions between neurons destined to the same cortical layer and between newly arrived neurons and the marginal zone barrier may then lead to termination of migration and delivery of neurons with corresponding birthdates to the newly forming cortical laminae at the top of the cortical plate (McConnell, 1988, 1989, 1991; Rakic, 1990; D'Arcangelo et al., 1995; Ogawa et al., 1995; Rakic and Caviness, 1995).

Based on their unique domain like cellular distribution, functional properties, and initial biochemical analysis, the junctional domain antigens recognized by our antibodies appear to be either novel molecules or previously known molecules that are not yet implicated in CNS development. The functional and initial biochemical properties of these molecules are consistent with the view that they belong to a family of cell adhesion molecules involved in specific glia-neuron adhesion, recognition events necessary for the oriented migration of neurons along radial glial processes. Importantly, the identification and functional characterization of these neuron-glial junctional molecules open the possibility to examine the mechanisms by which migrating neurons and radial glial cells induce, maintain, and dismantle the specialized contacts they form with each other during neuronal translocation across the developing cerebral wall.

\section{REFERENCES}

Antonicek H, Persohn E, Schachner M (1987) Biocliemical and functional characterization of a novel neuron-glia adhesion molecule that is involved in neuronal migration. J Cell Biol 104:1587-1595.

Barres BA, Koroshetz WJ, Chun LLY, Corey DP (1990) Ion channel expression by white matter glia: the type-1 astrocyte. Neuron 5:527-544.

Barth PG (1987) Disorders of neuronal migration. J Neurol Sci 14:1-16.

Boulder Committee Report (1970) Embryonic vertebrate central nervous system: revised terminology. Anat $\operatorname{Rec} 39: 287-293$. 
Cameron RS, Rakic P (1994) Identification of membrane proteins that comprise the plasmalemmal junction between migrating neurons and radial glial cells. J Neurosci 14:3139-3155.

Caviness VS, Rakic P (1978) Mechanisms of cortical development: a view from mutations in mice. Annu Rev Neurosci 1:297-326.

Caviness VS, Misson J-P, Gadisseux J-F (1989) Abnormal neuronal migrational patterns and disorders of neocortical development. In: From reading to ncuron (Galaburda AM, ed), pp 405-442. Cambridge: MIT.

Chuong CM, Crossin KL, Edelman GM (1987) Sequential expression and differential functions of multiple adhesive molecules during the formation of cerebellar cortical layers. J Cell Biol 104:331-342.

Chuong CM (1990) Differential roles of multiple adhesion molecules in cell migration: granule cell migration in cerebellum. Experientia 46:892-899.

D'Arcangelo G, Miao GG, Chen S-C, Suares HD, Morgan JI, Curren T (1995) A protein related to extracellular matrix proteins deleted in the mouse mutant reeler. Nature 374:719-723.

DeCamilli P, Cameron R, Greengard P (1983) Synapsin 1 (protein 1), a nerve terminal-specific phosphoprotein. I. Its general distribution in synapses of the central and peripheral nervous system demonstrated by immunofluorescence in frozen and plastic sections. J Cell Biol 96:1337-1354.

Edclman GM (1988) Modulation of cell adhesion during induction, histogenesis and perinatal development of the nervous system. Annu Rev Neurosci 7:339-377.

Edmondson JC, Hatten ME (1987) Glial-guided granule neuron migration in vitro: a high-resolution time-lapse video microscopy study. J Neurosci 7:1928-1934.

Edmondson JC, Licm RKH, Kuster JE, Hatten ME (1988) Astrotactin: a novel neuronal cell surface antigen that mediates neuron-astroglial interactions in cercbellar microcultures. J Cell Biol 106:505 517.

Evrard P, Caviness VS, Prats-Vinas J, Lyon G (1978) The mechanisms of arrest of neuronal migration in the Zellweger malformation: an hypothesis based upon cytoarchitectonic analysis. Acta Neuropathol (Berl) 41:109-117.

Falconer MM, Echeverri CJ, Brown DL (1992) Differential sorting of $\beta$-tubulin isotypes into colchicine-stable microtubules during ncuronal and muscle differentiation of embryonal carcinoma cells. Cell Motil Cytoskeleton 21:313-325.

Feng L, Heintz N (1995) Differentiating neurons activate transcription of the brain lipid-binding protein gene in radial glia through a novel regulatory element. Development 121:1719-1730.

Feng L, Hatten ME, Heintz N (1994) Brain lipid-binding protein (BLBP): a novel signaling system in the developing mammalian CNS. Neuron 12:895-908.

Fishell G, Hatten ME (1991) Astrotactin provides a receptor system for CNS neuronal migration. Development 113:755-765.

Fishman RB, Hatten ME (1993) Multiple receptor systems promote CNS neural migration. J Neurosci 13:3485-3495.

Galilco DS, Majors J, Ilorwitz AF, Sanes JR (1992) Retrovirally introduced antisense integrin RNA inhibits neuroblast migration in vivo Neuron 9:1117-1131.

Garcia-Segura LM, Rakic P (1985) Differential distribution of intermembranous particles in the plasmalemma of the migrating cerebellar granule cells. Brain Res 355:145-149.

Gasser UE, Hatten ME (1990) Central nervous system neurons migrate on astroglial fibers from heterotypic brain regions in vitro. Proc Natl Acad Sci USA 87:4543 4547

Gray GE, Leber SM, Sanes JR (1990) Migratory patterns of clonally related cells in the developing central nervous system. Experientia 46:929-939.

Gregory WA, Edmonson JC, Hatten ME, Mason CA (1988) Cytology and neuron-glial apposition of migrating cerebellar granule cells in vitro. J Neurosci 8:1728-1738.

Grumet M, Hoffman S, Crossin KL, Edelman GM (1985) Cytotactin, an extracellular matrix protein of neural and non-neural tissue that mediates neuron-glia interactions. Proc Natl Acad Sci USA 82:8075-8079.

Grumet M (1992) Structure, expression, and function of Ng-CAM, a Inember of the immunoglobulin superfamily involved in neuron-neuron and neuron-glia adhesion. J Neurosci Res 31:1-13.

Hatten ME, Liem RKH, Mason CA (1986) Weaver mouse cerebellar granule neurons fail to migrate on wild-type astroglial processes in vitro. J Neurosci 6:2676-2683
Hatten ME (1990) Riding the glial monorail: a common mechanism for glial-guided neuronal migration in different regions of the developing mammalian brain. Trends Neurosci 13:179-184.

Hatten ME, Mason CA (1990) Mechanisms of glial-guided migration in vitro and in vivo. Experientia 46:907-916.

Hatten ME (1993) The rolc of migration in central nervous system neuronal development. Curr Opin Neurobiol 3:38-44.

Hemmendinger LM, Caviness VS (1988) Cellular migration in developing cerebral wall explants in vitro. Dev Brain Res 38:290-295.

Kirkpatrick L, Brady SC (1994) Modulation of the axonal microtubule cytoskeleton by myelinating Schwann cells. J Neurosci 14:7440-7450.

Komuro H, Rakic P (1992) Selective role of N-type calcium channels in neuronal migration. Science 257:806-809.

Komuro H, Rakic P (1993) Modulation of neuronal migration by NMDA receptors. Science 260:95-97.

Komuro H, Rakic P (1995) Dynamics of granule cell migration: a confocal microscopic study in acute cerebellar slice preparations. J Neurosci $15: 1110-1120$.

Kunemund V, Jungalwala FB, Fischer G, Chou DK, Keilhauer G, Schachner M (1988) The L2/HNK-1 carbohydrate of neural cell adhesion molecule is involved in cell interactions. J Cell Biol 106:213-223.

Lee MK, Tuttle JB, Rebhun LL, Cleveland DW, Frankfurter A (1991) The expression and post-translational modification of a neuron-specific beta-tubulin isotype during chick embryogenesis. Cell Motil Cytoskeleton $17: 118-132$.

Lindner J, Rathgen FG, Schachner M (1983) L1 mono and poly clonal antibodies modify cell migration in early post natal mouse cerebellum. Nature 305:427-430.

McConnell SK (1988) Fates of visual cortical neurons in the ferret after isochronic and heterochronic transplantation. J Ncurosci 8:945-974.

McConmell SK (1989) The determination neuronal fate in the cerebral cortex. Trends Neurosci 12:342-349.

McConncll SM, Kaznowski CE (1991) Cell cycle dependence of laminar determination in developing neocortex. Science 251:282-285.

Misson J-P, Austin CP, Takahashi T, Cepko CL, Caviness VS (1991) The alignment of migrating neural cells in relation to neuropallial radial glial fiber system. Cercb Cortex 1:221-229.

Moskowitz PF, Oblinger MM (1995) Sensory neurons selectively upregulate synthesis and transport of the $\beta_{\mathrm{II}}$-tubulin protein during axonal regeneration. J Neurosci 15:1545-1555.

Ogawa M, Miyata T, Nakajima K, Yagyu K, Selke M, Ikenaka K, Yamamoto II, Mikoshiba K (1995) The reeler gene-associated antigen on Cajal-Retzius neurons is a crucial molecule for laminar organization of cortical neurons. Neuron 14:899-912.

O'Rourke NA, Dailey ME, Smith SJ, McConnell SM (1992) Diverse migratory pathways in the developing cerebral cortex. Science 258:299-302.

O'Rourke NA, Sullivan DP, Smith Kaznowski CE, Jacobs AA, McConnell SM (1995) Tangential migration of neurons in the developing cerebral cortex. Development 121:2165-2176.

Rakic P (1971) Neuron-glia relationship during granule cell migration in developing cercbellar cortex. A Golgi and electron microscopic study in Macacus rhesus. J Comp Neurol 141:283-312.

Rakic P (1972) Mode of cell migration to the superficial layers of fetal monkey neocortex. J Comp Neurol 145:61-84.

Rakic P (1978) Neuronal migration and contact guidance in the primate telencephalon. Postgrad Med J 54:25-40.

Rakic P (1985) Contact regulation of neuronal migration. In: The cell in contact. Adhesions and junctions as morphogenetic determinants (Edelman GP, Thiery J-P, eds), pp 67-91. New York: Wiley.

Rakic P (1988a) Specification of cerebral cortical areas. Science 241:170-176.

Rakic P (1988b) Defects of neuronal migration and pathogenesis of cortical malformations. Prog Brain Res 73:15-37.

Rakic P (1990) Principles of neural cell migration. Experientia 46:882-891.

Rakic P (1995a) Development of the cerebral cortex in human and non-human primates. In: Child and adolescent psychiatry, 2nd Ed (Lewis M, ed). Baltimore: Williams \& Wilkins.

Rakic P (1995b) Radial versus tangential migration of neuronal clones in the developing cerebral cortex. Proc Natl Acad Sci USA 92:11323-11327.

Rakic P, Caviness VS (1995) Cortical development: view from neurological mutants two decades later. Neuron 14:1101-1104.

Rakic P, Komuro H (1995) The role of receptor-channel activity in neuronal cell migration. J Neurobiol 26:299-315. 
Rakic P, Cameron RS, Komuro H (1994) Recognition, adhesion, transmembrane signaling, and cell motility in guided neuronal migration. Curr Opin Neurobiol 4:63-69.

Rakic P, Knyihar-Csillik E, Csillik B (1996) Polarity of microtubule assembly during neuronal cell migration. Proc Natl Acad Sci USA, in press.

Reiner O, Albrecht U, Gordon M, Chianese KA, Wong C, Gal-Gerber O, Sapir T, Siracusa LD, Buchberg AM, Caskey CT, Eichele G (1995) Lissencephaly gene (LIS1) expression in the CNS suggests a role in neuronal migration. J Neurosci 15:3730-3738.

Rivas RJ, Fishell G, Hatten ME (1991) Role of the cytoskeleton in glial-guided neuronal migration (Abstr). J Cell Biol 115:102A.

Rivas RJ, Hatten ME (1995) Motility and cytoskeletal organization of migrating cerebellar granule neurons. J Neurosci 15:981-989.

Roberts J, O'Rourke NA, McConnell SM (1993) Cell migration in cultured cerebral cortical slices. Dev Biol 155:396-408.

Rorke LB (1994) The role of disordered genetic control of neurogenesis in the pathogenesis of migration disorders. J Neuropathol Exp Neurol 53:105-117.

Rutishauser U, Jessell TM (1988) Cell adhesion molecules in vertebrate neural development. Physiol Rev 68:819-857.

Sanes JR (1989) Extracellular matrix molecules that influence neuronal development. Annu Rev Neurosci 12:491-516.
Schmechel DE, Rakic P (1979) A Golgi study of radial glial cells in developing monkey telencephalon. Anat Embryol 156:115-152.

Shimamura K, Takeichi M (1992) Local and transient expression of E-cadherin involved in mouse embryonic brain morphogenesis. Development 116:1011-1019.

Sidman RL, Rakic P (1973) Neuronal migration with special reference to developing human brain: a review. Brain Res 62:1-35.

Stipp CS, Litwack ED, Lander AD (1994) Cerebroglycan: an integral membrane sulfate proteoglycan that is unique to the developing nervous system and expressed specifically during neuronal differentiation. J Cell Biol 124:149-160.

Stitt TN, Hatten ME (1990) Antibodies that recognize astrotactin block granule neuron binding to astroglia. Neuron 5:639-649.

Takahashi T, Nowakowski RS, Caviness VS (1992) BI JdR as an S-phase marker for quantitative studies of cytokinetic behaviour in the murine cerebral ventricular zone. J Neurocytol 21:185-197.

Takeichi M (1991) Cadherin cell adhesion receptors as a morphogenetic regulator. Science 251:1451-1455.

Tomasiewicz H, Ono K, Yee D, Thompson C, Goridis C, Rutihauser U, Magnuson $T$ (1993) Genetic deletion of neural cell adhesion variant (N-CAM-180) produces distinct defects in the central nervous system. Neuron 11:1163-1174.

Volpe J (1987) Neurology of the newborn, 2nd Ed. Philadelphia: Saunders. 